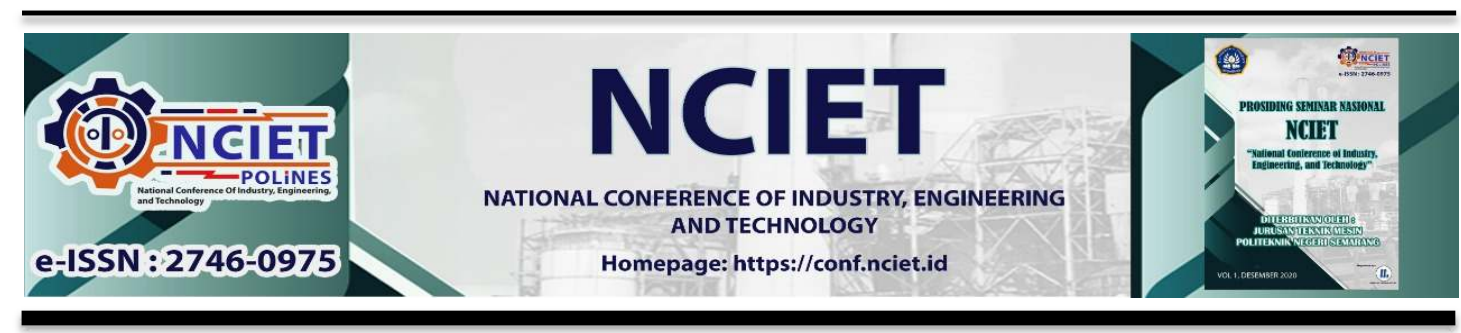

Prosiding Seminar Nasional NCIET Vol.1 (2020) B440-B449

$1^{\text {st }}$ National Conference of Industry, Engineering and Technology 2020,

Semarang, Indonesia.

\title{
PERANCANGAN PEMBANGKIT LISTRIK TENAGA SURYA TYPE SOLAR HOME SYSTEM DENGAN KAPASITAS 400 WP
}

\author{
Suwarti*, Budhi Prasetiyo, Gadang Satria Muflikhan, \\ Hoki Winahyu Mukti, Tiara Desy Longa \\ Jurusan Teknik Mesin, Politeknik Negeri Semarang \\ Jl. Prof H. Soedarto, SH, Tembalang, Semarang, 50275 \\ *Email: suwarti0707@gmail.com
}

\begin{abstract}
Abstrak
Tujuan dari penelitian perancangan pembangkit listrik tenaga surya type solar home system dengan kapasitas 400 WP adalah melakukan pengujian panel surya untuk menghidupkan peralatan rumah tangga seperti lampu, pompa, dan setrika. Membandingkan name plate dan output saat tidak berbeban maupun berbeban. Panel surya yang dipasang berjumlah enam buah dengan jenis poly-crystalline dayanya sebesar 50 watt berjumlah empat buah dan panel surya dengan jenis mono-crystalline dayanya sebesar 100 watt berjumlah dua buah. Dengan menggunakan Solar Charge Controller sebagai pengatur tegangan yang masuk ke baterai dan output beban. Energi panel surya disimpan dalam baterai yang berjumlah empat buah yang berkapasitas 24V 29Ah. Kemudian dirubah menjadi tegangan AC dengan inverter yang kapasitas $1600 \mathrm{~W} 24 \mathrm{~V}$ DC to AC220V. Pengambilan data dilakukan tiap 30 menit sekali mulai dari pukul 08.30 16.30 WIB. Dengan masing-masing beban setiap 30 menit didapatkan data, kemudian diperoleh harga tegangan solar cell pada beban pompa sebesar 26 Volt, arus solar cell sebesar 5 Ampere, Intensitas Cahaya Matahari $609,83 \mathrm{~W} / \mathrm{m}^{2}$, luas permukaaan panel surya sebesar $3,07 \mathrm{~m}^{2}$. Sehingga diperoleh harga efisiensi panel surya pada beban pompa sebesar $7 \%$.
\end{abstract}

Kata Kunci : PLTS, Efisiensi

\section{PENDAHULUAN}

Kebutuhan listrik masyarakat tidak hanya sebagai sarana penerangan, namun juga untuk menunjang segala kebutuhan di era modern saat ini. Seiring dengan berjalannya waktu harga tarif listrik PLN semakin mahal, oleh karena itu maka diperlukan inovasi untuk menciptakan sumber energi dengan memanfaatkan sinar matahari. Beberapa teknologi dikembangkan sebagai sumber energi alternatif untuk megatasi kebutuhan energi dimasa depan. Sumber energi alaternatif adalah sumber energi yang dapat diperbaharui. Salah satunya adalah Pembangkit Listrik Tenaga Surya ( PLTS ). Teknologi yang memanfaatkan energi matahari untuk diubah menjadi listrik.

Sistem ini biasanya digunakan untuk sistem listrik di pedesaan atau tempat terpencil 
yang belum teraliri arus listriik. Dalam penggunaan PLTS biasanya ditempatkan diatap rumah sehingga dapat memperoleh radiasi matahari secara langsung tanpa ada halangan. Untuk memperoleh keluaran yang maksimal dari PLTS, modul surya harus dipasang miring dengan sudut minimal $15^{\circ}$ yang merupakan standar pemasangan PLTS, modul fotovoltaik dengan komponen lain harus memiliki jarak yang dekat agar keluaran yang didapat bisa maksimal. Potensi energi surya yang ada dapat dimanfaatkan untuk memenuhi kebutuhan listrik oleh masyarakat, terlebih lagi ketersediaannya sangat besar untuk jangka waktu yang panjang dan ramah lingkungan. Sinar matahari yang ada dikonversi menjadi energi listrik oleh solar cell. Solar cell adalah sebuah elemen semikonduktor yang dapat mengkonversi energi surya menjadi energi listrik dengan prinsip photovoltaic.

Dalam penelitian ini penulis merancang PLTS dengan peletakan diatas atap rumah atau genteng dengan dikaitkan menggunakan tali kawat baja pada sisi panel surya satu dengan sisi panel surya yang lain supaya tidak terjatuh saat terkena angin.

Berdasarkan latar belakang yang telah diuraikan di atas, bisa dirumuskan suatu permasalahan tentang bagaimana cara merancang dan memasang pembangkit listrik tenaga surya yang dapat memperoleh output optimal, karena panel surya termasuk energi baru terbarukan dan sangat modern.

Tujuan dari penelitian yang berjudul "Perancangan Pembangkit Listrik Tenaga Surya Tipe Solar Home Sistem dengan Kapasitas 400 WP” yaitu :

1. Melakukan pengujian panel surya untuk menghidupkan peralatan rumah tangga seperti lampu, pompa, dan setrika.

2. Mengukur tegangan dari panel surya, arus dari panel surya,tegangan masuk baterai dan arus pada saat tanpa beban maupun diberi beban.

3. Membandingkan name plate dan hasil nyata panel surya.

\section{METODE PENELITIAN}

Metode pengambilan data dilakukan selama 10 hari yang dimulai dari tanggal 1 september sampai tanggal 10 september 2020. Metode pengambilan data dilakukan dengan cara mengukur tegangan output dan arus output dari panel surya dan menghitung daya input dengan cara mengalikan besaran intensitas cahaya matahari.Daya output yang digunakan didapat dari hasil perkalian antara tegangan output panel dengan arus output 
panel surya pada saat kondisi tanpa beban dan pada saat berbeban. Peralatan yang digunakan pada proses pengujian sistem pembangkit tenaga surya antara lain Voltmeter, Amperemeter, dan Wattmeter.Berikut merupakan gambar rangkaian instalasi panel surya yang sudah terpasang.

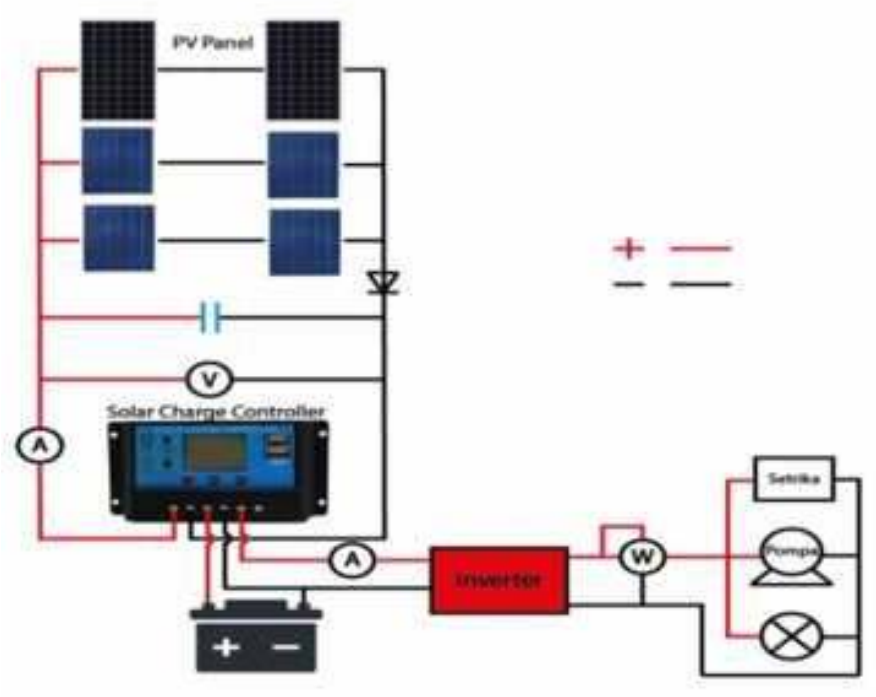

Gambar 1. Instalasi panel surya

Proses Perancangan Alat pada penelitian diawali dengan menentukan komponen yang digunakan. Dari berbagai komponen yang digunakan diperlukan untuk mengetahui fungsi dari masing - masing komponen dan cara kerja alat. Diagram peralatan dan komponen ditampilkan sebagai berikut.

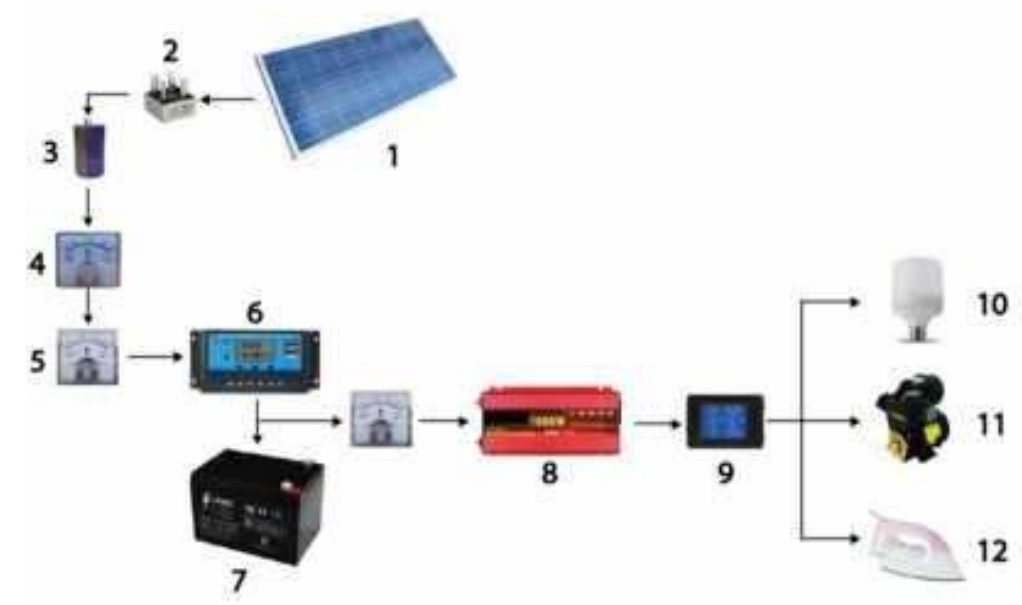

Gambar 2. Diagram peralatan dan komponen 
Berikut merupakan komponen utama yang digunakan dalam Perancangan sesuai dengan gambar 2, Diagram peralatan dan komponen :

1. Panel surya berfungsi untuk mengubah cahaya matahari menjadi energi listrik.

2. Dioda tipe britge.

3. Kapasitor berfungsi untuk menyimpan muatan lebih apabila baterai sudah penuh agar tegangan yang masuk tidak terbuang sia-sia.

4. Voltmeter berfungsi untuk mengukur besarnya tegangan listrik dalam rangkaian listrik.

5. Amperemeter berfungsi untuk mengukur besarnya arus listrik dalam rangkaian listrik.

6. Solar Charge Controller berfungsi untuk mengatur pengisian baterai dengan menggunakan modul fotovoltaik menjadi lebih optimal.

7. Baterai berfungsi untuk menyimpan energi listrik yang dihasilkan oleh panel surya.

8. Inverter berfungsi untuk mengubah tegangan dari DC menjadi AC.

9. Wattmeter adalah alat untuk mengukur daya listrik (atau tingkat pasokan energi listrik) dalam satuan watt dari setiap beban yang diansumsi pada suatu sirkuit rangkaian.

10.Lampu LED (Light Emitting Diode) adalah alat elektronik yang berfungsi sebagai penerangan.

11.Pompa air adalah alat untuk memindahkan fluida cair (air) dari tinggi tekan(head) rendah ketinggi tekan yang lebih tinggi.

12.Setrika.

Berikut merupakan langkah pengujian panel surya:

1. Memastikan kondisi alat ukur yang akan digunakan dalam kondisi baik.

2. Mencatat parameter yang terdisplay pada alat ukur saat tanpa diberi beban.

3. Selanjutnya mencatat parameter yang terdisplay pada alat ukur saat diberi beban lampu.

4. Selanjutnya mencatat parameter yang terdisplay pada alat ukur saat diberi beban setrika.

5. Selanjutnya mencatat parameter yang terdisplay pada alat ukur saat diberi beban pompa. 
6. Selanjutnya mencatat parameter terdisplay pada alat ukur saat diberi beban lampu dan setrika.

7. Selanjutnya mencatat parameter yang terdisplay pada alat ukur saat diberi beban lampu dan pompa.

8. Selanjutnya mencatat parameter yang telah terdisplay pada alat ukur saat beban setrika dan pompa.

9. Selanjutnya mencatat parameter yang telah terdisplay pada alat ukur saat beban lampu, setrika, dan pompa.

10.Selanjutnya menunggu selama 25 menit untuk melakukan pengujian dengan beban yang sama.

Setelah mendapatkan parameter-parameter yang diinginkan maka data tersebut dapat dingunakan untuk mencari efisiensi dengan perhitungan-perhitungan berikut:

a.Perhitungan daya output panel

$$
\text { surya } \mathrm{P}_{\text {out }}=\mathrm{V} \text { x I }
$$

Keterangan:

Pout = Daya Keluaran Modul Surya ( Watt)

$\mathrm{V} \quad=$ Tegangan Keluaran Modul Surya ( Volt )

I = Arus Keluaran Modul Surya (Ampere )

b. Perhitungan daya input

$$
\text { panel surya Pin } \quad=\text { Gu } \times \text { A }
$$

Keterangan:

$\mathrm{P}_{\text {in }} \quad=$ Daya input panel surya (Watt)

$\mathrm{Gu}=$ Intensitas Cahaya Matahari $\left(\mathrm{W} / \mathrm{m}^{2}\right)$

A $=$ Luas efektif dari modul fotovoltaik $\left(\mathrm{m}^{2}\right)$

c.Perhitungan Efisiensi Panel Surya

$\eta=P_{\text {out }} / P_{\text {in }}$

Keterangan :

Pout = Daya Keluaran Modul Surya ( Watt)

$\mathrm{P}_{\text {in }} \quad=$ Daya input panel surya (Watt) 


\section{HASIL DAN PEMBAHASAN}

Berikut merupakan data - data dan hasil perhitungan yang sudah didapatkan setelah mendapatkan parameter - parameter yang diinginkan. Pada jurnal ini akan ditampilkan data pengujian beban dengan kondisi tanpa beban, berbeban berupa lampu, setrika, dan pompa.Nilai - nilai parameter akan disajikan dalak bentuk tabel dan grafik.

Tabel 1. Hasil Perhitungan Efisiensi Pada Kondisi Tanpa Beban

\begin{tabular}{|l|l|l|l|l|}
\hline Pukul & Pin ( W ) & out ( V ) & but ( A ) & fisiensi \\
\hline 08.30 & 1872,18 & 5 & & $0_{0}$ \\
\hline 99.00 & 2173,41 & 5 & & $0_{0}$ \\
\hline 99.30 & 2432,76 & 5 & & 0 \\
\hline 10.00 & 2644,34 & 5,5 & & 0 \\
\hline 10.30 & 2803,49 & 5 & & 0 \\
\hline 11.00 & 3092,319 & 5 & & 0 \\
\hline 11.30 & 2952,235 & 7 & & 0 \\
\hline 12.00 & 2938,696 & & & 0 \\
\hline 12.30 & 2866,52 & 7 & & 0 \\
\hline 13.00 & 2737,181 & 7 & & 0 \\
\hline 13.30 & 2553,473 & 5 & & 0 \\
\hline 14.00 & 2319,324 & 5 & & 0 \\
\hline 14.30 & 2039,923 & 5 & & 0 \\
\hline 15.00 & 1721,871 & 5 & & 0 \\
\hline 15.30 & 1373,272 & 5 & & 0 \\
\hline 16.00 & 1004,627 & 5 & & 0 \\
\hline 16.30 & 630,8236 & 5 & & 0 \\
\hline
\end{tabular}

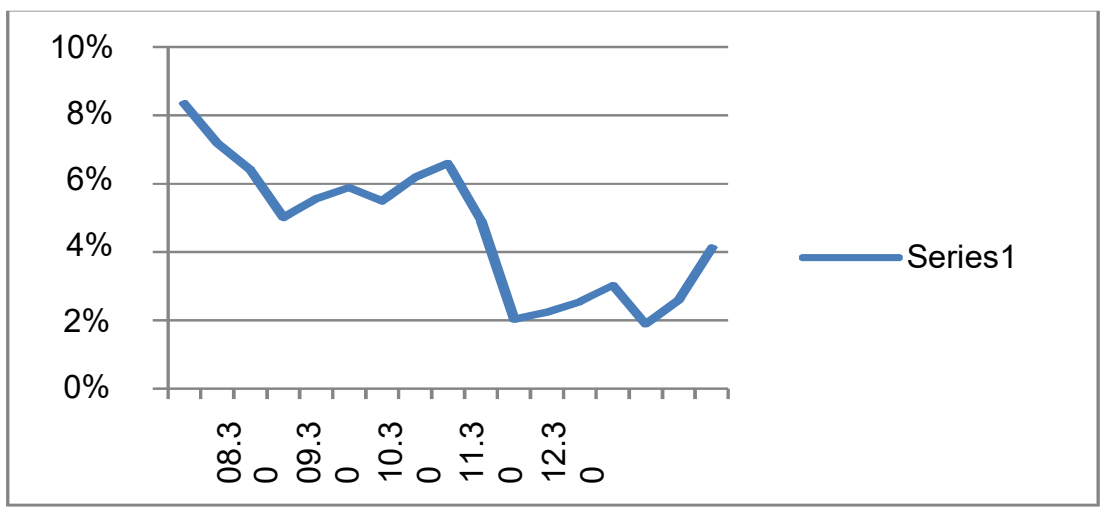

Grafik 1. Efisiensi ( sumbu Y ) vs Pukul ( sumbu X ) Pada Kondisi Tanpa Beban 
Tabel 2. Hasil Perhitungan Efisiensi Pada Kondisi Tanpa Beban Lampu 10 Watt

\begin{tabular}{|c|c|c|c|c|}
\hline Pukul & Pin (W) & out (V) & but (A) & fisiensi \\
\hline 08.30 & 872,18 & 5 & & \% \\
\hline 09.00 & 2173,41 & 5 & & \% \\
\hline 09.30 & 2432,76 & 5 & & \% \\
\hline 10.00 & 2644,34 & 5 & & Po \\
\hline 10.30 & 2803,493 & 5 & & \%o \\
\hline 11.00 & B092,319 & 5 & & \% \\
\hline 11.30 & 2952,235 & 5 & & Fo \\
\hline 12.00 & 2938,696 & 5 & & $\%$ \\
\hline 12.30 & 2866,52 & 5 & & $\%$ \\
\hline 13.00 & 2737,181 & 5 & & po \\
\hline 13.30 & 2553,473 & 5 & & \% \\
\hline 14.00 & 2319,324 & 5 & & \% \\
\hline 14.30 & 2039,923 & 5 & & $\%$ \\
\hline 15.00 & 1721,871 & 5 & & $\%$ \\
\hline 15.30 & 1373,272 & 5 & & \% \\
\hline 16.00 & 004,627 & 5 & & $\%$ \\
\hline 16.30 & 530,8236 & 5 & & \% \\
\hline
\end{tabular}

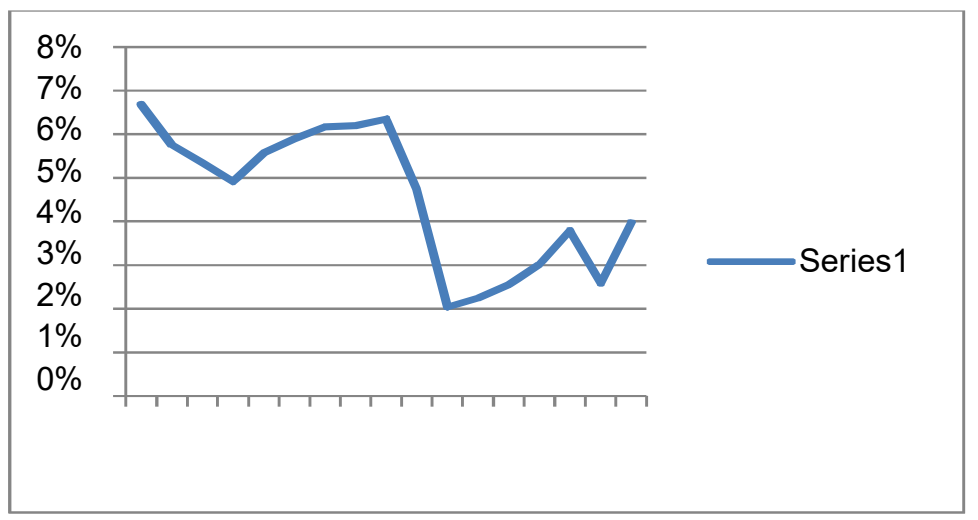

Grafik 2. Efisiensi ( sumbu Y ) vs Pukul ( sumbu X ) Pada Kondisi Beban Lampu 10 Watt 
Tabel 3. Hasil Perhitungan Efisiensi Pada Kondisi Tanpa Beban Setrika 350 Watt

\begin{tabular}{|c|c|c|c|c|}
\hline Pukul & $\operatorname{Pin}(\mathrm{W})$ & Vout (V) & Iout $(\mathrm{A})$ & Efisiensi \\
\hline 08.30 & 1872,18 & 25 & 5 & $7 \%$ \\
\hline 09.00 & 2173,41 & 25 & 4 & $5 \%$ \\
\hline 09.30 & 2432,76 & 24 & 4 & $4 \%$ \\
\hline 10.00 & 2644,34 & $\overline{25,5}$ & 4 & $4 \%$ \\
\hline 10.30 & 2803,493 & 26 & 4 & $4 \%$ \\
\hline 11.00 & 3092,319 & 26 & 7 & $6 \%$ \\
\hline 11.30 & 2952,235 & 26 & 7 & $6 \%$ \\
\hline 12.00 & 2938,696 & 25 & 7 & $6 \%$ \\
\hline 12.30 & 2866,52 & 26 & 7 & $6 \%$ \\
\hline 13.00 & 2737,181 & 26 & 5 & $5 \%$ \\
\hline 13.30 & 2553,473 & 25 & 2 & $2 \%$ \\
\hline$\overline{14.00}$ & 2319,324 & 25 & 2 & $2 \%$ \\
\hline 14.30 & 2039,923 & 25 & 2 & $2 \%$ \\
\hline 15.00 & 1721,871 & 25 & 2 & $3 \%$ \\
\hline 15.30 & 1373,272 & 24 & 1 & $2 \%$ \\
\hline 16.00 & 1004,627 & 25 & 1 & $2 \%$ \\
\hline 16.30 & 630,8236 & 25 & 1 & $4 \%$ \\
\hline
\end{tabular}

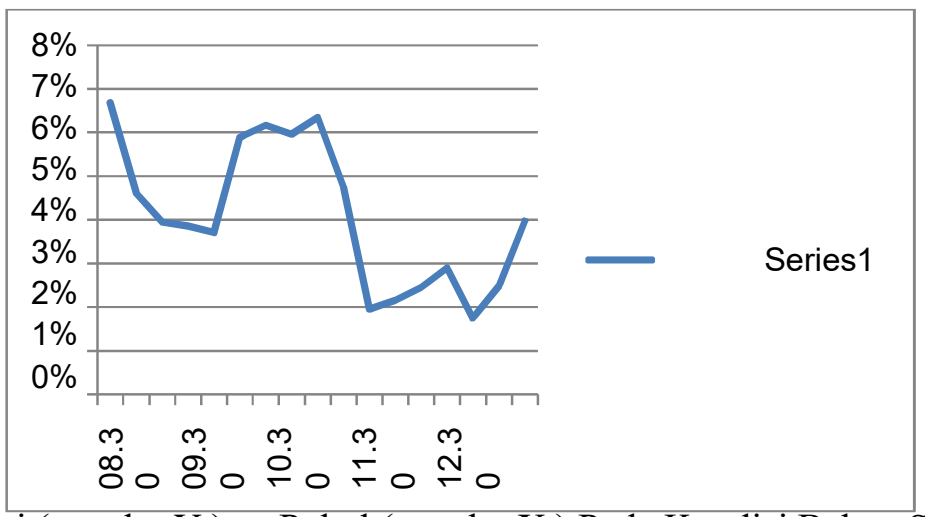

Grafik 3. Efisiensi ( sumbu Y) vs Pukul ( sumbu X) Pada Kondisi Beban Setrika 350

Watt

Tabel 4. Hasil Perhitungan Efisiensi Pada Kondisi Tanpa Beban Pompa 125 Watt

\begin{tabular}{|l|c|l|l|l|}
\hline Pukul & Pin ( W ) & out ( V ) & out ( A ) & fisiensi \\
\hline 08.30 & 1872,18 & 6 & & 0 \\
\hline 09.00 & 2173,41 & 6 & & 0 \\
\hline 09.30 & 2432,76 & 5 & & 0 \\
\hline 10.00 & 2644,34 & 6 & & 0 \\
\hline 10.30 & 2803,493 & 6 & & 0 \\
\hline 11.00 & 3092,319 & 6 & & 0 \\
\hline 11.30 & 2952,235 & 6 & & 0 \\
\hline 12.00 & 2938,696 & 5 & & 0 \\
\hline 12.30 & 2866,52 & 5 & & 0 \\
\hline 13.00 & 2737,181 & 5 & & 0 \\
\hline 13.30 & 2553,473 & 5 & & 0 \\
\hline 14.00 & 2319,324 & 5 & & 0 \\
\hline 14.30 & 2039,923 & 5 & & 0 \\
\hline 15.00 & 1721,871 & 5 & & 0 \\
\hline
\end{tabular}




\begin{tabular}{|l|l|l|l|l|}
\hline 15.30 & 1373,272 & 4 & $0_{0}$ \\
\hline 16.00 & 1004,627 & 5 & & $0_{0}$ \\
\hline 16.30 & 630,8236 & 5 & & $0_{0}$ \\
\hline
\end{tabular}

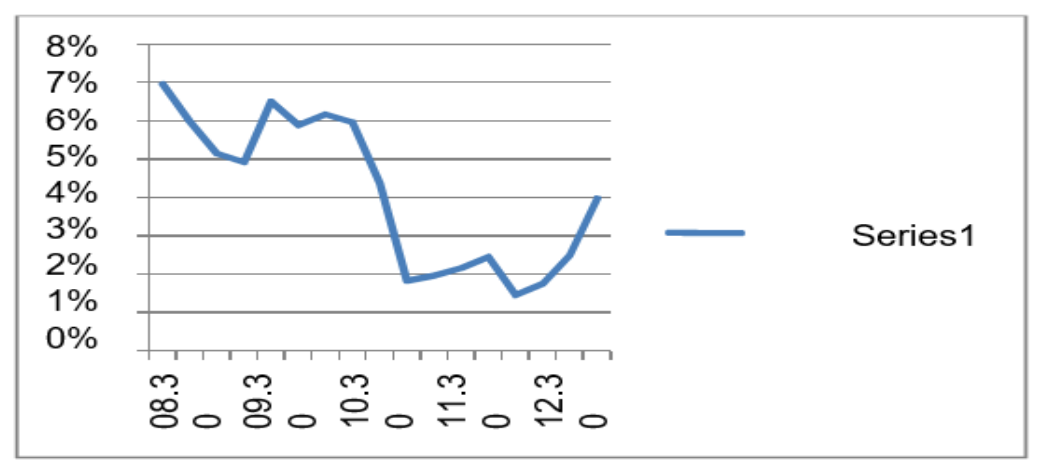

Grafik 4. Efisiensi ( sumbu Y ) vs Pukul ( sumbu X) Pada Kondisi Beban Pompa 125

Watt

\section{KESIMPULAN}

Berdasarkan hasil pengambilan data serta analisa yang telah dilakukan, diperoleh kesimpulan sebagai berikut.

1. Jadi berdasarkan pengujian alat yang telah dilakukan selama 10 hari. Perancangan Pembangkit Listrik Tenaga Surya Type Solar Home System dengan kapasitas 400 WP, mampu untuk menghidupkan peralatan rumah tangga seperti lampu, pompa, dan setrika.

2. Nilai tegangan input pada saat tanpa beban memiliki nilai rata-rata sebesar $26,6 \mathrm{~V}$ dan apabila diberikan beban mulai dari beban lampu terukur daya sebesar sebesar 9,45 Watt dan beban kombinasi dimana lampu, pompa, dan setrika dihidupkan secara bersamaan terukur daya sebesar 530,48 Watt semakin nilai beban bertambah maka nilai arus akan semakin besar dan nilai tegangan akan semakin kecil.

3. Hasil pengukuran ternyata memiliki perbedaan dengan spesifikasi komponenkomponen beban yang tertulis pada name plate seperti pada setrika, pada name plate setrika tertulus daya sebesar 350 Watt tetapi terukur 304-315 Watt. Pada saat ketiga beban dinyalakan yaitu lampu, pompa, dan setrika terukur daya sebesar 500 - 520 Watt padahal pada name plate panel surya keseluruhan apabila ditotal hanya berkapasitas 400WP. Tetapi pada saat ketiga beban dinyalakan tidak dapat berlangsung lama.

Selama pembuatan alat Perancangan Pembangkit Listrik Tenaga Surya Type Solar Home System dengan kapasitas 400 WP, terdapat banyak kendala sehingga dihasilkan beberapa 
saran dari penulis, adapun saran dari penulis adalah sebagai berikut :

1. Penambahan baterai supaya penyimpanan energi yang diserap panel surya lebih maksimal.

2. Memilih inverter sinus murni yang lebih baik supaya bisa menghasilkan perubahan listrik DC menjadi AC 220V lebih maksimal. Inverter khusus Panel Surya Type Solar Home System lebih baik menggunakan tegangan minimal 48 Volt dengan tujuan agar sistem PLTS menjadi lebih stabil.

\section{DAFTAR PUSTAKA}

Ramadhani,B.2018. Instalasi Pembangkit Listrik Tenaga Surya Dos\&Don'ts. Jakarta:GIZ

Utari, E. L. (2017). Perancangan alat inducsion heating pada pengolahan teh sangrai dengan teknologi energi terbarukan (solar cell). Teknoin, 23(3), 211-222.

Abdelkader, M. R., Al-Salaymeh, A., Al-Hamamre, Z., \& Sharaf, F. (2010). A comparative Analysis of the Performance of Monocrystalline and Multiycrystalline PV Cells in Semi Arid Climate Conditions: the Case of Jordan. Jordan Journal of Mechanical \& Industrial Engineering, 4(5).

PARASTIWI, A., PUTRI, R. I., ADHISUWIGNJO, S., \& RIFA, M. (2018). Photovoltaic Terapan: Photovoltaic Terapan (Vol. 1). UPT Percetakan dan Penerbitan Polinema.

Rusman, R. (2017). PENGARUH VARIASI BEBAN TERHADAP EFISIENSI SOLAR CELL DENGAN KAPASITAS 50 WP. Turbo: Jurnal Program Studi Teknik Mesin, 4(2).

Putama, D. G. (2019). ANALISIS TEKNIS DAN EKONOMI PEMBANGKIT LISTRIK TENAGA SURYA DI KABUPATEN ROKAN HILIR, KECAMATAN PUJUD, DESA AIR HITAM (Doctoral dissertation, Universitas Islam Negeri Sultan Syarif Kasim Riau).

Bangun, B. D. (2017). Rancang Bangun Inverter Sinus Murni DC ke AC BerdayaRendah Berbasis Mikrokontroller Atmega328.

Iswanto, Ady.(2008). Prinsip Dasar Solar Cell, Staf Divisi Riset 102FM ITB, Bandung 